\title{
Pilon kırıklarının komplikasyonları
}

\author{
Complications of pilon fractures
}

\author{
Mert Kumbaracı, Önder Kalenderer
}

Tepecik Eğitim ve Araştırma Hastanesi Ortopedi ve Travmatoloji Kliniği, İzmir

Pilon kırıklarının sonuçları; travmanın şiddetine, yumuşak dokunun durumuna, tedavi şekline, eşlik eden hastalıklara ve cerrahi sonrası rehabilitasyona bağlı olarak değişebilmektedir. Cerrahi girişim sırasında yumuşak dokuya gerekli özenin gösterilmemesi, tedavisi güç yumuşak doku problemlerine neden olabilmektedir. Yumuşak dokunun öneminin anlaşılması ve gelişen implant teknolojilerine rağmen günümüzde pilon kırıklarından sonra hala komplikasyonlar görülebilmektedir. En sık erken dönem komplikasyonu olarak, yüzeyel cilt nekrozu ve yara dudaklarında açılma görülmektedir. Yüzeyel cilt nekrozları yara bakımı ile tedavi edilebilirken, derin enfeksiyonlar debridman ve antibiyotik tedavisi gerektirmektedir. Geç dönem komplikasyonları ise yanlış kaynama, kaynama gecikmesi, kaynamama, osteomiyelit ve post-travmatik artrozdur. Özellikle geç enfeksiyon ya da osteomiyelit zemininde gelişen kaynamama tedavisi çok zordur. Tekrarlayan debridmanlar ile, tüm enfekte ve nekrotik kemikler ve implantlar çıkarılır. Kemik defektleri antibiyotikli kemik çimentosu ile doldurulur. Eksternal fiksatörler, enfeksiyon kontrol altına alınıncaya kadar kırığın stabilitesinin sağlanmasında ya da kalıcı tedavide kullanılabilir. İleri evre artrozun tedavisinde, ayak bileği artrodezi en güvenilir tedavi olarak görülmektedir. Artrodez için, tibianın diziliminin sağlanmış olması ve kırı̆̆ın kaynamış olması gerekmektedir. Artrodez amacıyla; vidalar, bıçaklı plaklar, füzyon çivileri ve sirküler eksternal fiksatörler kullanılabilir. Ayak bileği artroplastisi, semptomatik post-travmatik ayak bileği artrozunun tedavisinde kullanılan bir başka tedavi seçeneğidir. Ancak bu yöntemin uygulanabilmesi için; sağlıklı yumuşak doku örtüsü, minimal deformite, vaskülarize kemik ve kırı̆̆ın iyileşmiş olması gerekmektedir. Ayak bileği artroplastisi sonrasında yara yeri problemleri, mediyal ya da lateral malleolde kırık, protezde gevşeme gibi komplikasyonlar görülebilmektedir.

Anahtar sözcükler: pilon kırıkları; komplikasyon; fonksiyonel sonuçlar; ayak bileği artrozu
Clinical outcomes of pilon fractures of tibia may vary depending on severity of trauma, status of soft tissues, choice of treatment, comorbidities, and postoperative rehabilitation. Careless handling of soft tissues during surgical procedure may cause problems that are troublesome to treat afterwards. Contemporarily, despite of understanding of the importance of soft tissues and development of newer implant technologies, complications may still be encountered after pilon fractures of the tibia. The most common early postoperative complications are superficial skin necrosis and wound dehiscence. While the superficial skin necrosis could be treated with local wound care, deep infections require debridement and use of antibiotics. Late complications include malunion, union delay, nonunion, osteomyelitis, and post-traumatic arthrosis. Especially late infections or nonunions caused by osteomyelitis are very difficult to treat. All of the implants, besides the necrotic and infected bone tissue are removed completely with repetitive debridements. Bone defects are augmented with antibiotics loaded bone cement. External fixators may be used to stabilize the fracture until the infection is under control. Arthrodesis of the ankle joint is considered to be the most reliable treatment of advanced arthrosis. Obtaining a normal alignment of tibia, and a complete fracture healing is required to perform arthrodesis. Blade plates, fusion nails, ring external fixators may be used to perform arthrodesis. Ankle joint arthroplasty is another treatment choice of symptomatic post-traumatic ankle joint arthrosis. But for this procedure, healthy soft tissue coverage, minimal deformity, and vascularized bone are necessary. Such complications as wound healing problems, fractures of medial or lateral malleoli, and loosening of components may be seen after an ankle arthroplasty

Key words: pilon fractures; complication; functional outcomes; ankle arthrosis

- İletişim adresi: Dr. Önder Kalenderer, Tepecik Eğitim ve Araştırma Hastanesi, Ortopedi ve Travmatoloji Kliniği, İzmir Tel: 0232 - 4443560 e-posta: okalenderer@gmail.com

- Geliş tarihi: 3 Mayıs 2016 Kabul tarihi: 3 Mayıs 2016 
ilon kırıkları, tibia distalinin eklem içi uzanım gösteren, parçalı kırıklarıdır. Bu kırıklar, genellikle yüksek enerjili yaralanmalar sonucunda ve aksiyel yüklenme ile oluşur ve hemen her zaman cerrahi olarak tedavi edilir. Cerrahi tedavide amaç; yumuşak dokunun özenli disseksiyonu sonrası eklem yüzünün anatomik rekonstrüksiyonu ve erken harekete izin verecek şekilde kemiğin stabil olarak osteosentezidir. ${ }^{[1]}$ Bu yaralanmaların tedavisinde ameliyat öncesi planlama ve zamanlama çok önemlidir. Yumuşak doku iyileşmesi beklenmeden yapılan açık redüksiyon ve plaklı tespitler sonucunda, sık olarak yumuşak doku problemleri görülmektedir. ${ }^{[2]}$ Pilon kırıklarının sonuçları; travmanın şiddetine, yumuşak dokunun durumuna, tedavi şekline, eşlik eden hastalıklara ve rehabilitasyona bağlı olarak değişebilmektedir. Bu kırıkların cerrahi tedavisinden sonra görülen komplikasyonlar, erken ve geç komplikasyonlar olarak ikiye ayrılır. ${ }^{[3]}$

\section{ERKEN KOMPLIKASYONLAR}

Pilon kırıkları, ayak ve ayak bileğinde ileri derecede şişlik, açık yaralar ve cilt defektleri ile birliktelik gösterebilir. Şişlik, ayağın kan akımının bozulmasına, bacakta ve ayakta kompartman sendromu gelişmesine ve bül oluşumu sonrası gelişebilen cilt lezyonlarına neden olabilir. Tibia distalinin anteromediyal bölgesinde cilt altında kas dokusunun bulunmaması nedeniyle, bu bölgenin kanlanması zayıftır. Bu nedenle, disseksiyon sırasında yumuşak dokuya gerekli özenin gösterilmemesi ve bu bölgede gereğinden fazla yapılan periosteal sıyrılma, cildin ve altındaki kemiğin beslenmesinin bozulmasına neden olabilmektedir. ${ }^{[4]}$

Yüzeyel yara nekrozu, pilon kırıklarının açık redüksiyon ve internal tespit ile tedavisinden sonra en sık görülen erken komplikasyondur. ${ }^{[5]}$ Ameliyat öncesinde cilt optimal duruma gelse de, cerrahi sonrası dönemde yara dudaklarında nekroz sık olarak görülür. Cildin tüm katlarını içermeyen bu kısmi nekroz, kendisini kuru skar dokusu olarak gösterir. Bu doku, altındaki epitelyum dokusunun rejenerasyonu sayesinde iyileşme potansiyeline sahiptir. ${ }^{[1]}$ Skar dokusunun debridmanı ve tekrarlayan pansumanlar, yara iyileşmesi için yeterlidir. Sıklıkla, skar dokusunun çevresinde kızarıklık görülür. Bu kızarıklığın nedeni, enfeksiyondan daha çok lokal inflamatuvar yanıttır; bu durumda, ekstremitenin elevasyonu ve skar olgunlaşıncaya kadar rehabilitasyona ara verilmesi yeterlidir. ${ }^{[1,5]}$ Sellülit tablosu oluştuğunda, yüzeyel bakteriyel enfeksiyon düşünülüp antibiyotik tedavisine başlanmalıdır. Cilt florası ile kontaminasyon olabileceğinden, yara kültürleri yol gösterici değildir. ${ }^{[4]}$

Cildin tüm katmanlarını içeren kabuk ya da yara dudaklarındaki açılma, genelde derin enfeksiyon ile birliktedir (Şekil 1). Derin enfeksiyon oranlarının \%55'e kadar çıkabileceğini bildiren çalışmalar vardır. ${ }^{[6,7]}$

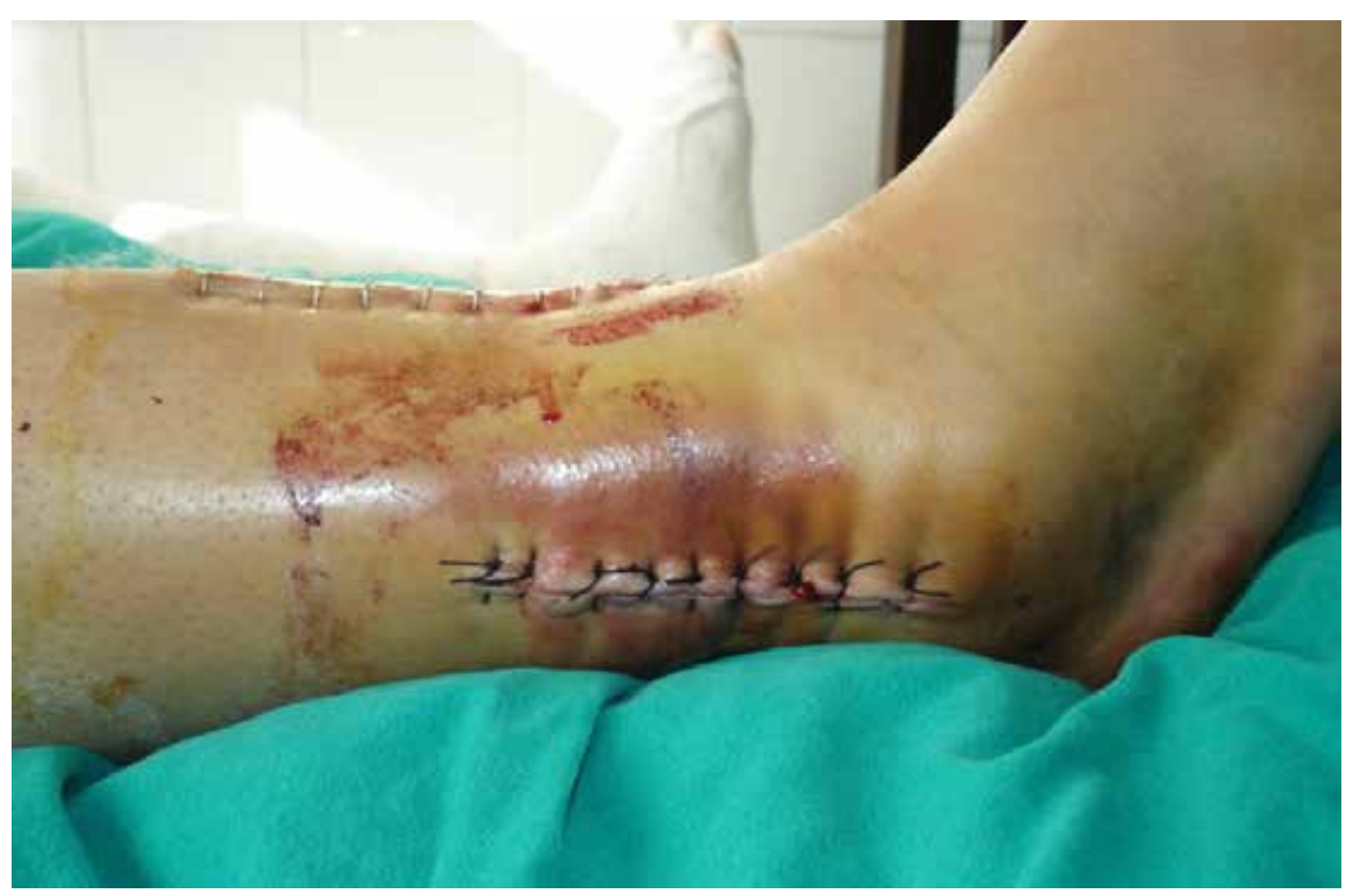

Şekil 1. Tibia pilon kırı̆̆ı cerrahi tedavisi sonrası yumuşak doku hematomu ve erken enfeksiyon bulguları. 

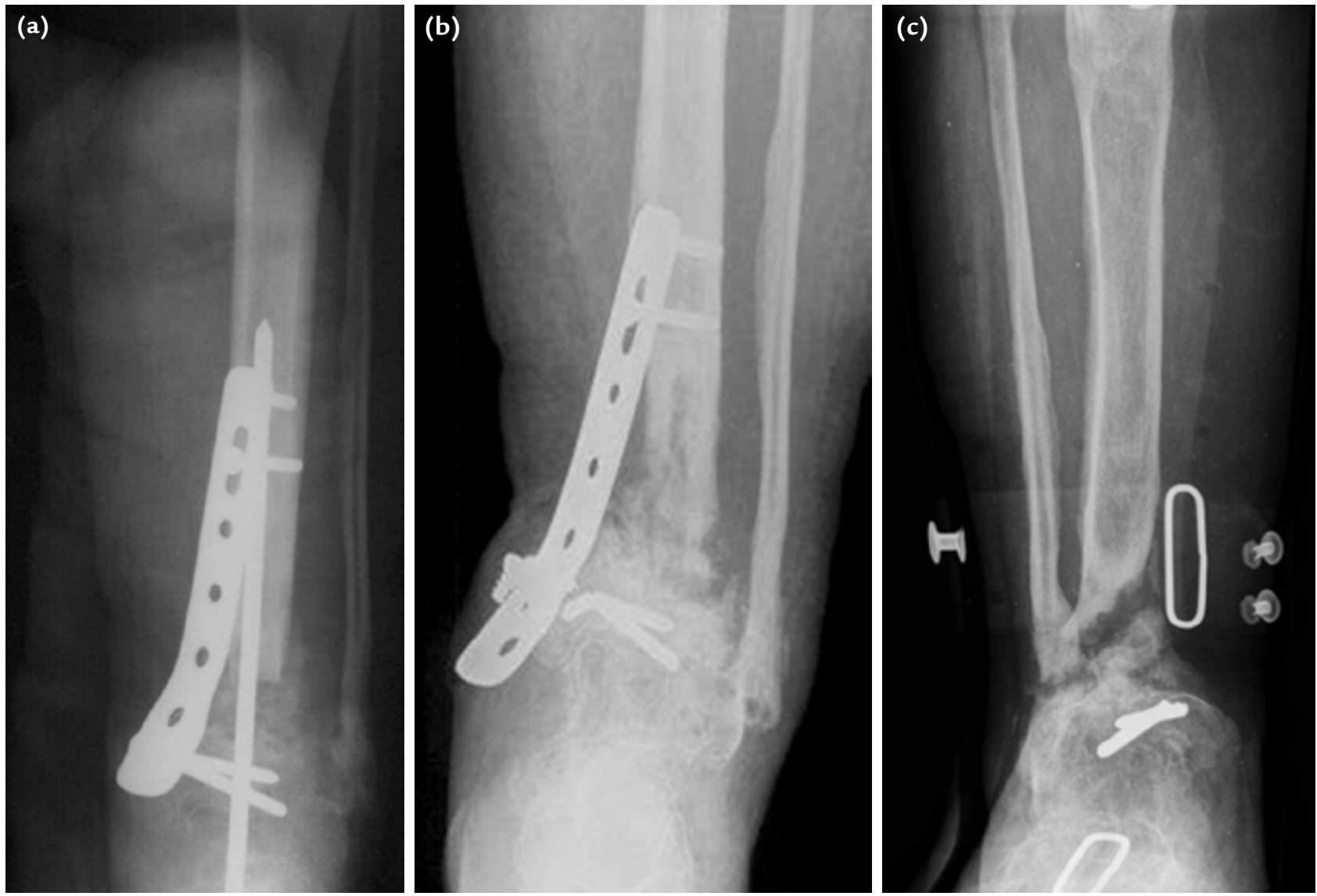

Şekil 2. a-c. Tibia pilon kırığı tedavisi sonrası osteomiyelit ve kaynamama.

Kontamine olan cerrahi saha, debridman ile steril hale getirilmeye çalışılır. Bu amaçla, pürülan ve nekrotik doku kalmayıncaya kadar, debridmanlar her 48-72 saatte bir tekrarlanmalıdır. Cerrahi işlem sırasında derin doku kültürü alınmalı, kemik ve implantların stabilitesi kontrol edilmelidir. Enfeksiyonun kontrol altında alınabilmesi için, kırığın stabilitesi önemlidir. Bu nedenle, sadece fazlaca gevşemiş olan implantlar çıkarılmalı, diğerleri bırakılmalıdır. Lokal olarak enfeksiyon tedavisinde antibiyotikli polimetil metakrilat boncukları kullanılabilir. Kültür sonucuna uygun olarak başlanan sistemik antibiyotik tedavisine altı hafta devam edilmelidir. Enfeksiyonun tedaviye yanıtı, haftalık eritrosit sedimentasyon hızı ve C-reaktif protein takipleri ile değerlendirilir. Yara dudaklarının bir araya getirilip primer olarak kapatılamadığı durumlarda, negatif basınçlı yara tedavisinden yararlanılmalıdır. Tekrarlayan vakum değişimlerinden sonra, yara temizse ve nekrotik dokulardan arındırıldıysa, küçük defektler cilt grefti ya da rotasyonel flepler ile kapatılmalıdır. Kemik, tendonlar ya da implantlar açıkta ise yara serbest doku transferleri ile kapatılmalıdır. ${ }^{[8]}$ Unutulmamalıdır ki yara, kapatma sırasında ne kadar temiz görünürse görünsün, eğer implantların üzerinde bakteriyel kolonizasyon mevcutsa, geç enfeksiyon görülme riski bulunmaktadır. ${ }^{[1]}$

\section{GEÇ KOMPLIKASYONLAR}

Geç komplikasyonlar, genellikle yaralanmanın şiddeti ve ameliyat öncesi veya sonrasında yumuşak dokunun durumu ile ilişkilidir. ${ }^{[9]}$

Geç ve kronik enfeksiyonlar, genellikle osteomiyelit ve kontamine implantlarla ilişkilidir (Şekil 2). Radyolojik ve klinik olarak kaynama gözlenen kırık üzerinde gelişen akut yara yeri enfeksiyonun tedavisi göreceli olarak daha kolaydır. ${ }^{[10]}$ Tüm enfekte implantlar çıkarılıp debridman uygulandıktan sonra, enfeksiyon uygun antibiyoterapi ile kontrol altına alınabilir. ${ }^{[1,10]}$ Kırıkta kaynamanın gözlenmediği kronik enfeksiyonların tedavisi ise son derece güçtür. ${ }^{[3]}$ Debridman sırasında tüm nekrotik kemikler çıkarılır. Canlı ve ölü kemik dokularının 
ayrımında “laser Doppler flowmeter" kullanımı önerilmektedir. ${ }^{[1]}$ Medulla temizlenir ve korteks yüksek hızlı burr ile debride edilir. Kemikte yeterli temizlik ve sterilizasyon sağlanamazsa implantlar çıkarılır. Gerektiği takdirde, debridmanlar tüm nekrotik ve enfekte dokular uzaklaştırılıncaya kadar tekrarlanır. Kemikteki defektler antibiyotikli sement ile doldurulabilir. Yumuşak doku defektleri ise serbest doku flepleri ile kapatılır. [11] Enfeksiyon kontrol altına alınıncaya kadar, kırı̆ı̆ın stabilitesinin sağlanmasında eksternal fiksatörler kullanılabilir. Antibiyotik tedavisine, enfeksiyon hastalıkları uzmanının kontrolünde 6-12 hafta devam edilir. Kesin tedaviye, yumuşak doku iyileşmesi ve epitelizasyon tamamlandıktan sonra karar verilmelidir. Kırık kaynaması tamamlanıncaya kadar eksternal fiksatör ile tedaviye devam edilebileceği gibi, fiksatör çıkarılıp kemik greftleri ve plaklarla da osteosentez sağlanabilir. ${ }^{[1]}$ illeri derecede yumuşak doku yaralanması olan hastalarda enfeksiyon gelişmesi durumunda, hastanın fonksiyonel ve psikososyal durumları da göz önünde bulundurularak, ampütasyon önerilebilmektedir. Her ne kadar ekstremitenin kurtarılması birincil amaç olsa da, kemik ve yumuşak doku kaybı fazla, enfekte ve beraberinde de diyabet, immün yetmezlik ve malnütrisyon gibi sistemik problemleri olan hastalarda, erken ampütasyon daha etkili olabilir. ${ }^{[1,10]}$

Pilon kırıklarında ameliyat sonrası eklem sertliği sık olarak görülür. Hareket kısıtlılığı, travma sırasında eklem kıkırdaklarındaki hasarın yanı sıra çevre yumuşak dokudaki yaralanmanın miktarına ve immobilizasyon süresine bağlı olarak değişmektedir. ${ }^{[5]}$ Artroskopik olarak, tibianın anteriorunda ya da talus boynunda gelişen osteofitler eksize edilerek hareket genişliği arttırılabilir. ${ }^{[12]}$ Artrofibrozis ya da eklem çevresindeki skar dokularına bağlı hareket kısıtlılığının tedavisi ise güçtür. Artroskopik debridman ya da anestezi altında yapılan manipülasyonların sonuçları yüz güldürücü değildir. Bununla birlikte, ayak bileğinde ekin pozisyonunda kontraktür var ise, Aşil tendon uzatmaları ve posterior eklem gevşetmeleri sıklıkla iyi sonuç vermektedir. ${ }^{\left[{ }^{[5}\right.}$

Pilon kırıkları sonrasında görülen yanlış kaynamalar, çözümü zor ve karmaşık problemlerdir (Şekil 3). ${ }^{[13,14]}$ Tedaviye başlamadan önce deformitenin anlaşılması gerekir. Koronal ve sagittal plandaki açılanmalar, rotasyonel deformiteler, tibia eklem yüzünün fibula olan ilişkisi ve kısalık değerlendirilmeli; planlama bu parametreler üzerinden yapılmalıdır. Ayrıca, tibia distalini çevreleyen yumuşak doku örtüsünün durumu göz önünde bulundurulmalıdır. Deformitenin ayak bileği eklemine uzaklığı, malunion bölgesinde kemik dokusunun canlılığı ve medüller kanalın durumuna bakılarak, kanal içi çivileme, eksternal fiksatör ve plaklı tespit yöntemlerinden

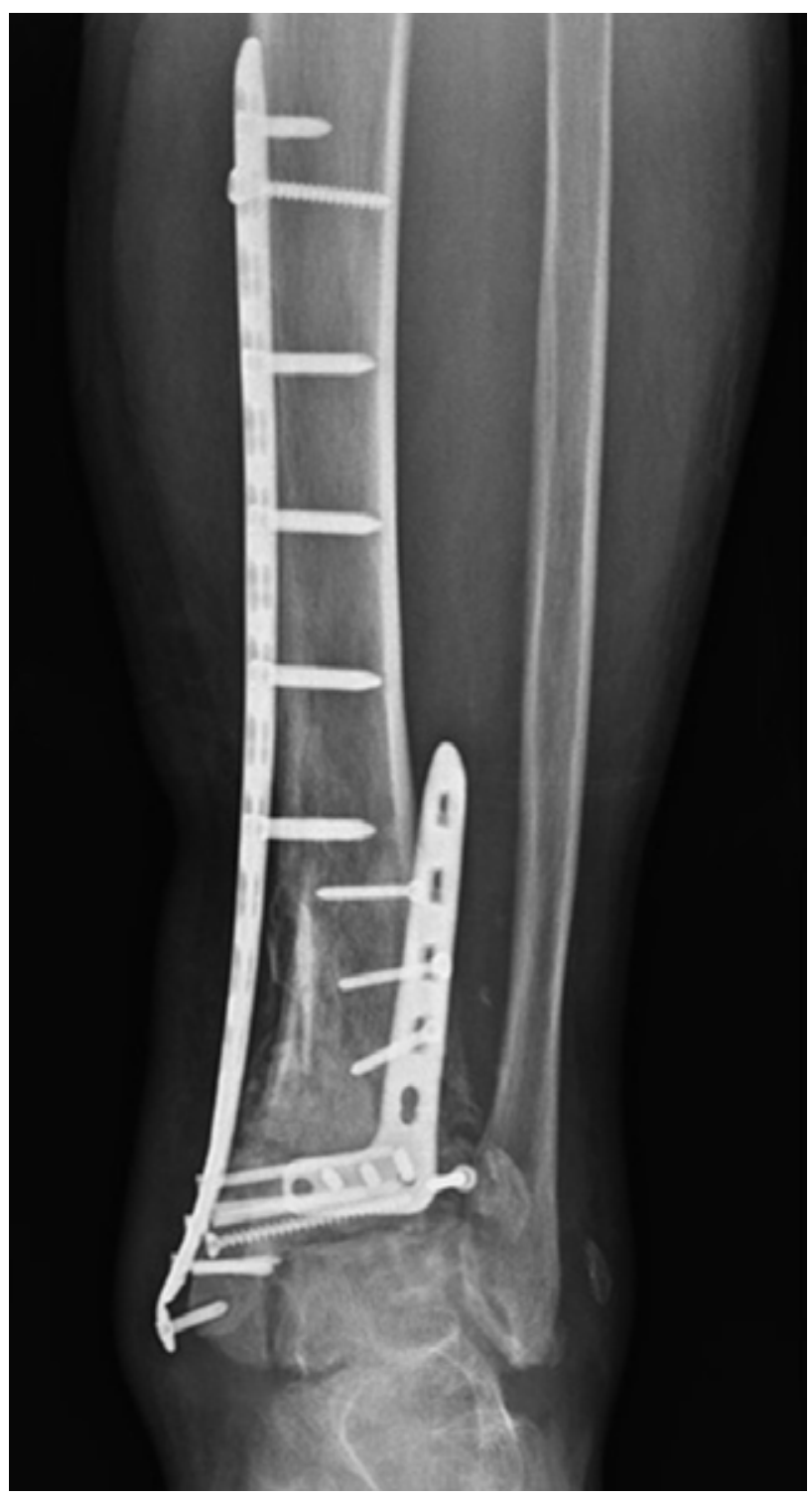

Şekil 3. Tibia pilon kırığı tedavisi sonrası ayak bileğinde ekleminde deformite.

biri seçilebilir. ${ }^{[15,16]}$ Deformite düzeltildikten sonra oluşan kemik defektleri, yapısal kemik greftleri ile doldurulabilir. Ileri derecede deformiteler, eksternal fiksatör yardımı ile tedavi edilebilir. ${ }^{[15]}$

Literatürde, pilon kırıkları sonrası gecikmiş kaynama ve kaynamama oranları \%4-36 arasında değişmektedir (Şekil 4). ${ }^{[15-18]}$ Özellikle metafizer bölgedeki ileri derecede parçalanma ve kemik kaybı kaynamama riskini arttırmaktadır. ${ }^{[15]}$ Eksternal fiksatör ile tedavi edilen hastalarda, metafiz-diyafiz bileşkesinde kaynamama oranı plakla tedavi edilenlere göre daha fazladır. Bunun nedeni olarak, metafiz ve diyafize uygulanan 

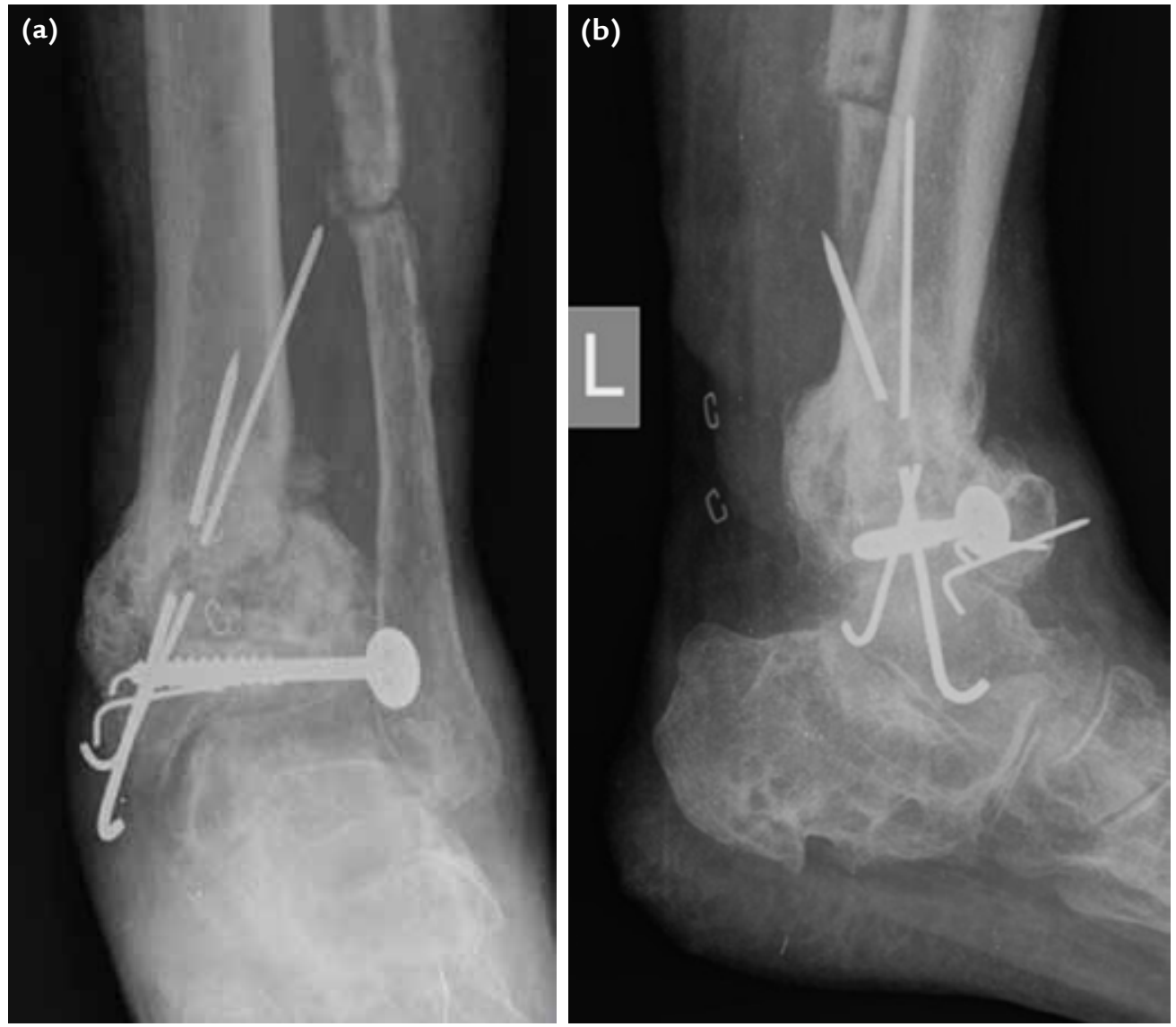

Şekil 4. a, b. Tibia pilon kırığı tedavisi sonrası kaynamama.

yetersiz stabilizasyon gösterilmiştir.[19] Kaynamama riskini azaltmak için, erken ya da geç dönemde greftleme önerilmektedir. Uzmanlar, geç greftleme için en uygun zamanın 4. ve 8 . haftalar arasında olduğunu ileri sürmektedirler. ${ }^{[20]}$ Defektin $7 \mathrm{~cm}$ ve üzerinde olduğu durumlarda; fibula strut allogreftler, vaskülarize kemik greftleri ya da kemik transport tekniği kullanılabilir. ${ }^{[21]}$

Pilon kırıklarının en sık görülen uzun dönem komplikasyonu, post-travmatik artrozdur (Şekil 5). Travma sırasında kondrositlerin geri dönüşümsüz hasarı, subkondral kemikte oluşan osteonekroz ve kırık redüksiyon kalitesi, artroz gelişimindeki en önemli parametreler olarak gösterilmiştir. ${ }^{[5]}$ Travmanın şiddeti arttıkça, artroz gelişme riskinin de artacağı ileri sürülmektedir. Eklem yüzü anatomik olarak redükte edilse bile, tibia ve talustaki kıkırdak hasarlarına bağlı olarak artrozik değişiklikler gelişebilmektedir. ${ }^{[22]}$ Hastanın şikayetleri ve çekilen ayak bileği grafilerindeki bulgular her zaman paralellik göstermez. ${ }^{[5,23]}$ Tedavide, öncelikle non-steroid anti-inflamatuvar ilaçlar, ayakkabı ve aktivite modifikasyonları denenir. Topukta yapılacak bir miktar yükseltme, ayak bileği anteriorundaki osteofitten dolayı, kısıtlı olan dorsifleksiyonda rahatlamaya neden olabilir. Ayak bileği eklemine yapılan steroid enjeksiyonları semptomları azaltabilir. Distraksiyon artroplastisinin tek başına ya da fasya interpozisyonu ile birlikte uygulanması önerilmekte, fakat bu teknikle ilgili geniş olgu serilerini kapsayan uzun dönem takipli çalışmalar bulunmamaktadır. ${ }^{5,10]}$

Pilon kırığı sonrasında gelişen son evre ayak bileği artrozunun en güvenilir tedavisi, ayak bileği artrodezidir. $^{[22,24,25]}$ Artrodez için, tibianın diziliminin sağlanmış olması ve kırığın kaynamış olması gerekir. Vidalar, bıçaklı plaklar, füzyon çivileri ve sirküler eksternal fiksatörler kullanılabilir. ${ }^{[22,24,25]}$ Artrodez, genellikle açık olarak uygulanır. Daha önceden uygulanan implantlar çıkartılır, kemik defektleri ve subkondral kistler greftlenir, deformite düzeltilerek ve ayağa uygun pozisyon verilerek artrodez uygulanır. Genellikle önerilen, ayak plantigrad pozisyonda iken arka kısmına hafif valgus verilerek, ayak bileğine artrodez uygulanmasıdır. Subtalar eklem ve midtarsal eklemlerdeki hareket, 

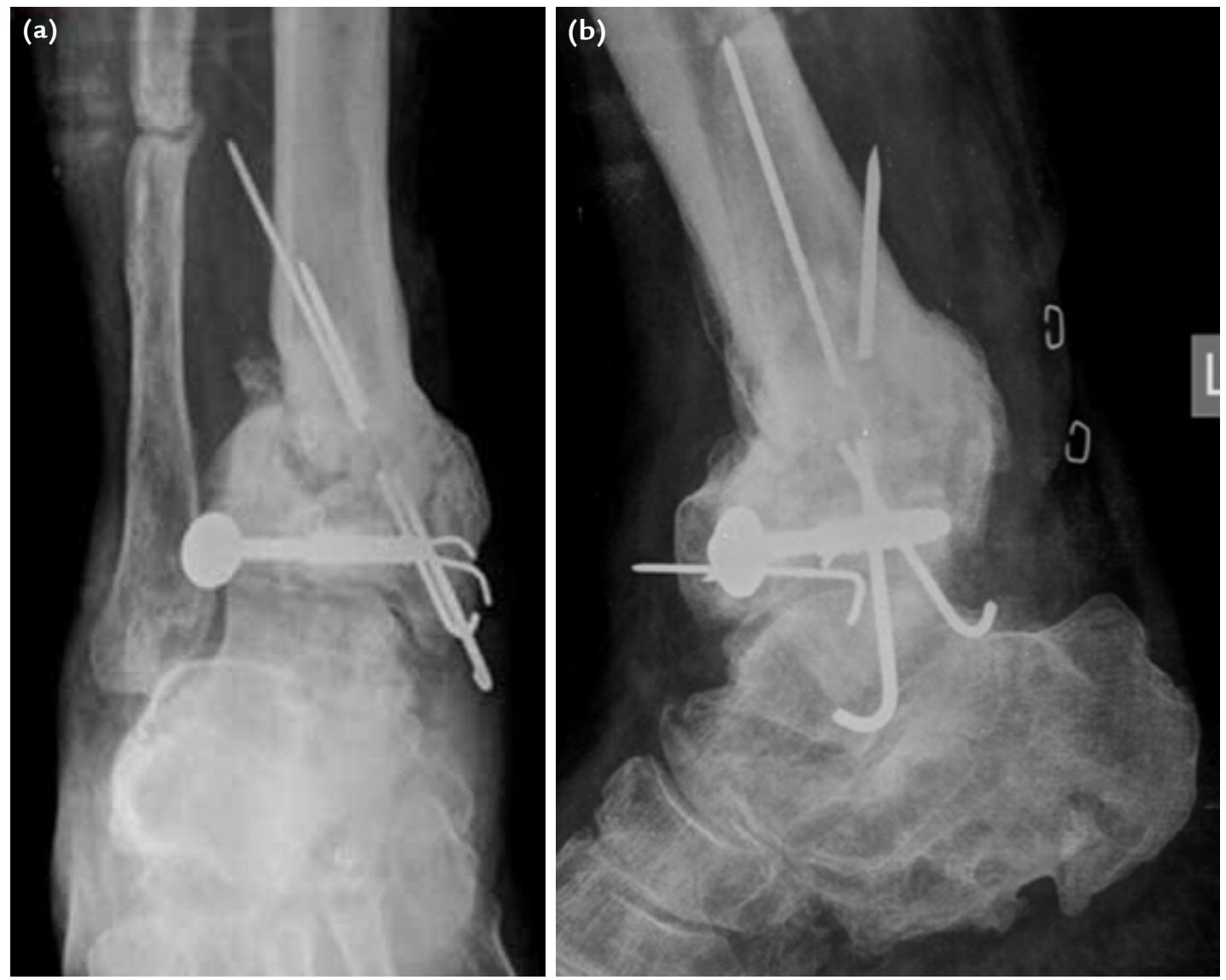

Şekil 5. a, b. Tibia pilon kırığı tedavisi sonrası ayak bileğinde artroz ve deformite.

mümkünse korunmalıdır. Artrodez öncesi, özellikle subtalar eklemdeki artritik değişiklikler değerlendirilmelidir. Enfeksiyonun varlığında ise artrodez iki aşamalı olarak yapılmalıdır. Birinci aşamada implantlar çıkarılmalı, debridman uygulanıp antibiyotikli sementler ile defektler doldurulmalıdır. İkinci aşamada ise definitif artrodez uygulanmalıdır. İleri derecede deformite varlığında ise artrodez, yumuşak doku örtünmesinde problemler yaşanabileceği göz önünde bulundurularak, akut kısaltma ile yapılmalıdır. ${ }^{[24]}$ Alternatif olarak, multiplanar eksternal fiksatör yardımıyla deformite düzeltilmesi ile artrodez ve ekstremiteyi uzatma işlemleri birlikte uygulanabilir. ${ }^{[25]}$ Artrodez sonrası hastalar, kısa ve orta dönem ağrılarında belirgin azalma, uzun dönem takiplerde ise subtalar ve midtarsal eklemlerde gelişen dejeneratif artrit sonucunda ağrı ve fonksiyonel kısıtlılık tanımlarlar. ${ }^{[22,24,25]}$

Ayak bileği artroplastisi, semptomatik posttravmatik ayak bileği artrozunun tedavisinde kullanılan bir başka tedavi seçeneğidir. Bu yöntemin uygulanabilmesi için, sağlıklı yumuşak doku örtüsü, minimal deformite, vazkülarize kemik ve kırığın iyileşmiş olması, en önemlisi ise, ayak bileğinde enfeksiyon bulgularının olmaması gerekmektedir. ${ }^{[26]}$ Birçok çalışmada, ayak bileği artroplastisi sonrasında yara yeri problemleri, mediyal ya da lateral malleolde kırık, protezde gevşeme gibi komplikasyonların geliştiği gösterilmiştir. ${ }^{[26-28]}$ Tüm literatürün gözden geçirildiği bir derlemede, beş yıl sonunda ayak bileği protezlerinde \%10-30 oranında gevşeme ve revizyon gerekliliği, artroplasti sonrası subtalar ve talonaviküler eklemlerde de artroz görüldüğü bildirilmiştir.[26] Bu bilgiler ışığında, ayak bileği protezlerinin komşu eklemleri korumadığı ve bu eklemlerde artroz gelişimine ya da var olan artrozun artmasına neden olabildiği söylenebilir. ${ }^{[27]}$ Gelecekte, implant tasarımındaki gelişme ve ilerlemeler bu protezlerin kullanımını arttırabilir.

Yapılan çalışmalar, pilon kırı̆̆ı sonrası hastaların yaklaşık 1/3'ünde ayak bileğinde ağrı, kalıcı şişlik ve topallama görüldüğünü bildirmektedir. ${ }^{[1,10]}$ Pilon kırıklı hastaların yaşam kaliteleri, kendi yaş grubundaki 
genel popülasyonla karşılaştıııldığında, belirgin olarak düşmektedir. Bununla birlikte, hastalarda uykusuzluk, anksiyete bozukluğu ve depresyon gibi psikolojik sorunlara da rastlanmaktadır. ${ }^{[17-21]}$ Kırık sonrası gelişen komplikasyonlar hastanın işine dönme süresini uzatmakta, bu da hastaların ekonomik sıkıntılar yaşamasına neden olmaktadır. Hastaların bir kısmı bu kırık sonrası işlerini kaybetmektedir. ${ }^{[29]}$

\section{KAYNAKLAR}

1. Barei DP. Pilon fractures. In: Court-Brown CM, Heckman JD, McQueen MM, Ricci WM, Tornetta P 3rd. Rockwood and Green's fractures in adults. Philadelphia: Wolters Kluwer Health; 2015. p.2473-540.

2. Pollak AN, McCarthy ML, Bess RS, Agel J, Swiontkowski MF. Outcomes after treatment of high-energy tibial plafond fractures. J Bone Joint Surg Am 2003;85-A(10):1893-900.

3. Mader JT, Shirtliff M, Calhaun JH. Staging and staging application in osteomyelitis. Clin Infect Dis 1997;25(6):1303-9.

4. McCann PA, Jackson M, Mitchell ST, Atkins RM. Complications of definitive open reduction and internal fixation of pilon fractures of the distal tibia. Int Orthop 2011;35(3):413-8. Crossref

5. Thordarson DB. Complications after treatment of tibia pilon fractures: prevention and management strategies. J Am Acad Orthop Surg 2000;8(4):253-65.

6. Molina CS, Stinner DJ, Fras AR, Evans JM. Risk factors of deep infection in operatively treated pilon fractures (AO/ OTA:43). J Orthop 2015;12(Suppl 1):S7-S13. Crossref

7. Molina CS, Stinner DJ, Fras AR, Evans JM. Course of treatment and rate of successful salvage following the diagnosis of deep infection in patients treated for pilon fractures (AO/OTA:43). J Orthop 2015;12(Suppl 1):S18-24. Crossref

8. Trumble TE, Benirschke SK, Vedder NB. Use of radial forearm flaps to treat complications of closed pilon fractures. J Orthop Trauma 1992;6(3):358-65.

9. Deivaraju C, Vlasak R, Sadasivan K. Staged treatment of pilon fractures. J Orthop 2015;12(Suppl 1):S1-6. Crossref

10. Liporace FA, Mehta S, Rhorer AS, Yoon RC, Reilly MC. Staged treatment and associated complications of pilon fractures. Instr Course Lect 2012;61:53-70.

11. Zalavras CG, Patzakis MJ, Thordarson DB, Shah S, Sherman $R$, Holtom P. Infected fractures of the distal tibial metaphysis and plafond: achievement of limb salvage with free muscle flaps, bone grafting and ankle fusion. Clin Orthop Relat Res 2004;(427):57-62.

12. Van Dijk CN, Verhagen RA, Tol JL. Arthroscopy for problems after ankle fracture. J Bone Joint Surg Br 1997;79:280-4.

13. Bacon S, Smith WR, Morgan SJ, Hasenboehler E, Philips G, Williams A, Ziran BH, Stahel PF. A retrospective analysis of communited intraarticular fractures of the tibial plafond: Open reduction and internal fixation versus external Ilizarov fixation. Injury 2008;39(2):196-202. Crossref
14. Grose A, Gardner MJ, Hettrich C, Fishman F, Lorich DG, Asprinio DE, Helfet DL. Open reduction and internal fixation of tibial pilon fractures using a lateral approach. J Orthop Trauma 2007;21(8):530-7.

15. Rozbruch SR, Fragomen AT, Ilizarov S. Correction of tibial deformity with use of the Ilizarov-Taylor spatial frame. J Bone Joint Surg Am 2006;88 Suppl 4:156-74.

16. Feldman DS, Shin SS, Madan S. Correction of tibial malunion and nonunion with six-axis analysis deformity correction using Taylor Spatial frame. J Orthop Trauma 2003;17(8):549-54.

17. Chan R, Taylor BC, Gentile J. Optimal Management of HighEnergy Pilon Fractures. Ortopedics 2015;38(8):e708-14. Crossref

18. Gardner MJ, Mehta S, Barei DP, Nork SE. Treatment protocol for open AO/OTA type C3 pilon fractures with segmental bone loss. J Orthop Trauma 2008;22(7):451-7. Crossref

19. Calori GM, Tagliabue L, Mazza E, de Bellis U, Pierannunzii L, Marelli BM, Colombo M, Albisetti W. Tibial pilon fractures: which method of treatment? Injury 2010;41(11):1183-90. Crossref

20. Wyrsch B, McFerran MA, McAndrew M, Limbird TJ, Harper MC, Johnson KD, Schwartz HS. Operative treatment of fractures of the tibial plafond. A randomized, prospective study. J Bone Joint Surg Am 1996;78(11):1646-57.

21. Conroy J, Agarwal M, Giannoudis PV, Matthews SJ. Early internal fixation and soft tissue cover of severe open tibial pilon fractures. Int Orthop 2003;27(6):343-7.

22. Coester LM, Saltzman CL, Leupod J, Pontarelli W. Longterm results following ankle arthrodesis for post-traumatic arthritis. J Bone Joint Surg Am 2001;83-A(2):219-28.

23. Kalenderer $\mathrm{O}$, Güneş $\mathrm{O}$, Özçalabi IT, Ozlük $\mathrm{S}$. Clinical results of tibial pilon fractures treated by open reduction and internal fixation. Acta Orthop Traumatol Turc 2003;37(2):133-7.

24. Morgan SJ, Thordarson DB, Shepherd LE. Salvage of tibial pilon fractures using fusion of the ankle with a 90 degrees cannulated blade-plate: a preliminary report. Foot Ankle Int 1999;20(6):375-8.

25. Morrey BF, Wiedeman GP Jr. Complications and long-term results of ankle arthrodesis following trauma. J Bone Joint Surg Am 1980;62(5):777-84.

26. Easley ME, Adams SB Jr, Hembree WC, DeOrio JK. Results of total ankle arthroplasty. J Bone Joint Surg Am 2011;93(15):1455-68. Crossref

27. Gougoulias NE, Khanna A, Maffulli N. How successful are current ankle replacements?: a systematic review of the literature. Clin Orthop Relat Res 2010;468(1):199-208. Crossref

28. Knecht SI, Estin M, Callaghan JJ, Zimmerman MB, Alliman KJ, Alvine FG, Saltzman CL. The Agility total ankle arthroplasty. Seven to sixteen-year follow-up. J Bone Joint Surg Am 2004;86-A(6):1161-71.

29. Volgas D, DeVries JG, Stannard JP. Short-term financial outcomes of pilon fractures. J Foot Ankle Surg 2010;49(1):4751. Crossref 